\title{
Reducing Downtime Equipment in LPM Machine Line Using DMAIC Approach at an Alloy Wheel Manufacturer in Indonesia
}

\author{
Hadi Ashary ${ }^{1}$, Choesnul Jaqin ${ }^{2}$ \\ ${ }^{1,2}$ Master's Program in Industrial Engineering, Mercu Buana University, Jakarta, Indonesia
}

\begin{abstract}
One effort that can be undertaken by manufacturing companies to maintain the stability of production is by maintaining equipment or machines to prevent damage. The alloy wheel manufacturing company in Karawang is one of the companies that produce casting wheels. The high production capacity of the allow wheel manufacturer has caused the high frequency of machine breakdown, particularly in the LPM machine line, which often goes into breakdowns. DMAIC (Define, Measure, Analyze, Improvement, Control) is one method used to analyze and make improvements in quality as well as in other processes. This study was conducted employing the DMAIC method, from defining the problem of the causes of downtime to implementing improvement actions. The improvement actions undertaken were carried out directly on the machine, in which methods used were standardization of materials used, reparation of working tools used, and skills improvement of the technical operator. The downtime was successfully reduced, the sigma score improved, and the use of spare parts reduced after improvement.
\end{abstract}

Keywords: DMAIC, Downtime, LPM, Alloy, Wheel, Sigma Level

\section{Introduction}

As a company operating in the field of alloy wheel manufacturing, they frequently experience machine breakdown at high levels. The more frequent the engine runs to meet production targets which at times exceed the capacity, the lower the machine ability and machine lifetime; in addition to requiring replacement for damaged components more often [1]. This hinders the production process, resulting in the decline in production capacity. In general, the cause of production disturbance can be categorized into three factors, which are human, machine, and environment. The most important factor of these conditions is the machine performance that is used [2]. The company implements a corrective maintenance system, which is to repair the machine when damage occurs. Maintenance is an activity that is required to maintain the facilities in a desired condition so that it meets its production capacity [3]. Maintenance is all activities related to maintaining the level of availability and reliability system and also maintain the components ability to work according to specified quality standards [4]. Maintenance is also the company's logistics function which is usually integrated into the production process [5]. Basically, the main principle in the treatment management system is to suppress the breakdown period to a minimum, then the decision about component replacement system based on the minimum downtime becomes very important [6].

According to the production department data, the production line which often experiences issues in the production process is the LPM production machine. The LPM machine is a machine used for the initial stage of cast wheel production. If the LPM machine stops, the cast wheel making process halts. The production division frequently complains about the major downtime problem in the LPM line machine. Therefore, it is necessary to find out the main cause of the downtime occurrence and make improvements accordingly to overcome the issue.

One method that can be employed as a problem solving tool to overcome machine breakdowns is the DMAIC approach. The six sigma approach uses the DMAIC analysis to support the development of the hot rolling mill machine's capability and elimination of downtime in one of the processes in the aluminum industry [8]. Afterwards, the approach is used to determine critical downtime and reveal the cause of the damage in the production machine. Therefore, this approach can be employed in making suggestions for improvement in the maintenance system by implementing a precaution system.

\section{Methodology}

DMAIC is the basic component of the Six Sigma methodology, employed to improve the performance of a process by eliminating defects [9]. DMAIC is carried out systematically, based on knowledge and facts. This process removes unproductive processes, and frequently focuses on the new measurements, as well as setting technology to improve quality to achieve the targets of Six Sigma. [10].

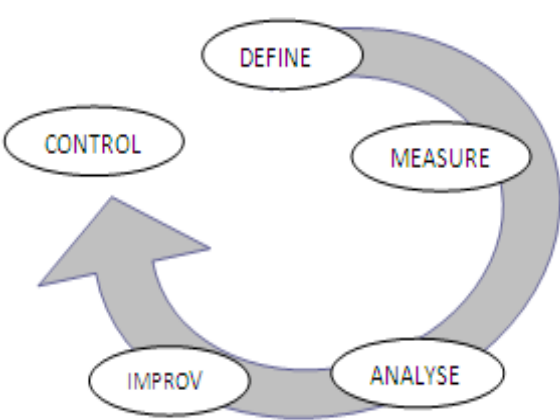

Figure 1: The DMAIC Process 


\section{International Journal of Science and Research (IJSR) \\ ISSN (Online): 2319-7064}

Index Copernicus Value (2013): 6.14 | Impact Factor (2015): 6.391

DMAIC is shortened from:

a)Define, which is the formulation of the problem that may also become part of customer's complaint, goals of a project, or desired specifications.

b) Measure, which is the measurements of key aspects of the existing process and the gathering of necessary relevant data.

c)Analysis, which is the analysis of the gathered data to conduct investigation and verification of cause-effect relationship (root causes of problem).

d)Improve, which is the reparation or improvement of the existing process based on data analysis using techniques such as design experiment, poka-yoke or mistake-proofing, which then creates or establishes a new standard.

e) Control, which is the control or monitoring of the process or new standard that has been determined to ensure that each deviation must be corrected before a defect occurs.

\section{Results}

\subsection{Define}

At this alloy wheel manufacturer located in Indonesia, there are several production processes from the raw material to the final product, starting from casting - X-ray - heat treatment machining process to painting, as shown in Figure 2.
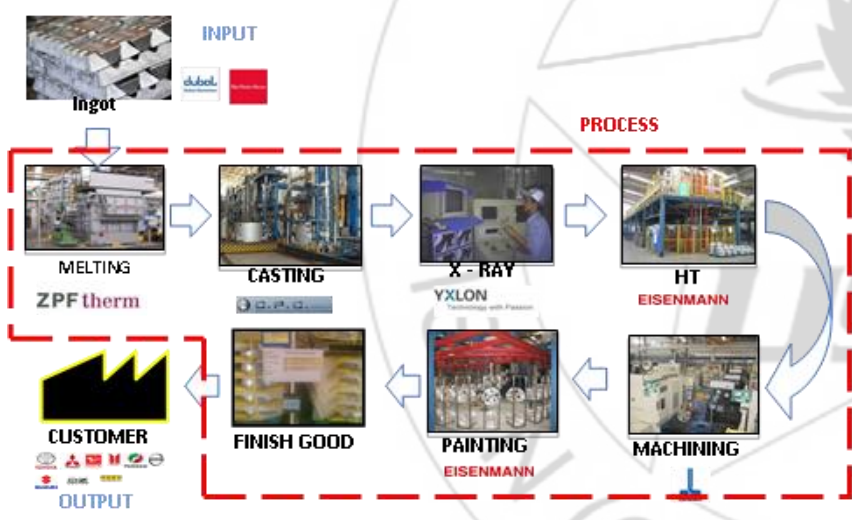

Figure 2: The Production Process

\subsection{Data on Machine Damage}

Based on the data from the production report of January to June 2015, specifically on downtime, DTE's highest problem was the LPM line compared to the other lines due to several factors. In January, LPM line had the highest downtime of 5,360 minutes, followed by line 4 with a downtime of 4,675 minutes. In February, LPM line had the highest downtime of 14,554 minutes, followed by line 1 with a downtime of 9,358 minutes. In March, LPM line had the highest downtime of 17,250 minutes, followed by line 1 with a downtime of 9,497 minutes. In April, line 1 had the highest downtime of 9,274 minutes, followed by LPM line with a downtime of 8,541 minutes. In May, LPM line had the highest downtime of 15,780 minutes, followed by line 4 with a downtime of 10,111 minutes. Lastly in June, LPM line had the highest downtime of 17,303 minutes, followed by line 4 with a downtime of 11,658 minutes. Based on these line downtime data, this study was conducted in the LPM line because the
LPM line downtime average from January to June 2015 was the highest among the others.

The following chart is derived from the data above, based on the item grouping pareto to understand the main problem which caused the high DTE in LPM line, as seen in Figure 3 below:

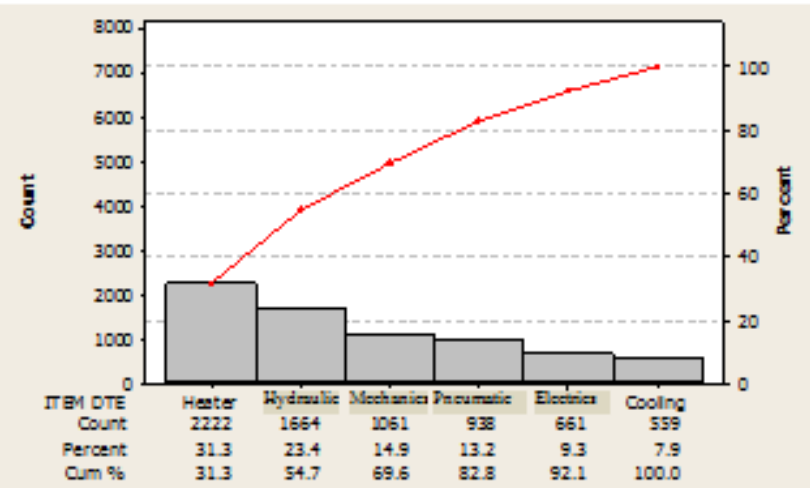

Figure 3: Pareto Chart of DTE LPM Line based on Damage Item

Based on the figure above, this study will discuss the highest item in the Pareto diagram, which is DTE due to the heater.

\subsection{Analysis on Potential Savings}

Table 1: Data on Part Replacement, January-June 2015

\begin{tabular}{|c|c|c|c|}
\hline \multirow{2}{*}{ Month } & \multicolumn{3}{|c|}{ Part Replacement } \\
\cline { 2 - 4 } & Fuse & Glowbar & Heater \\
\hline January & 5 & 4 & 5 \\
\hline February & 13 & 13 & 13 \\
\hline March & 11 & 9 & 11 \\
\hline April & 6 & 5 & 6 \\
\hline May & 7 & 7 & 7 \\
\hline June & 4 & 4 & 4 \\
\hline Total & 46 & 42 & 46 \\
\hline
\end{tabular}

Based on inventory control purchase data report, the spare parts in heater system LPM machine costed IDR 2,480,000 for 1 pcs of Stainless Glowbar, IDR 594,500 for 1 pcs of Fuse Busman $125 \mathrm{~A}$, and IDR 4,170,000 for 1 pcs of heater kanthal $\varnothing 32 \mathrm{~mm}$. The costs of using the part of each item from January to June 2015 were:

Fuse Part $=$ Total of Part Replacement $\mathrm{x}$ Price of Part

$$
\begin{aligned}
& =46 \text { pcs } \times \text { IDR 594,500 } \\
& =\text { IDR } 27,347,000.00
\end{aligned}
$$

Glowbar Part $=$ Total of Part Replacement $\mathrm{x}$ Price of Part

$$
\begin{aligned}
& =42 \text { pcs } x \text { IDR 2,480,000.00 } \\
& =\text { IDR 104,160,000.00 }
\end{aligned}
$$

Heater Part $=$ Total of Part Replacement $\mathrm{x}$ Price of Part $=46 \mathrm{pcs} \times$ IDR $4,170,000.00$

$=$ IDR $191,820,000.00$

Therefore, the total costs of part replacement for all items from January to June 2015 was:

$=$ Total Fuse Part + Total Glowbar Part + Total Heater Part $=$ IDR 27,347,000 + IDR 104,160,000 + IDR 191,820,000

$=\operatorname{IDR} 323,327,000$ 


\section{International Journal of Science and Research (IJSR) \\ ISSN (Online): 2319-7064}

Index Copernicus Value (2013): 6.14 | Impact Factor (2015): 6.391

\subsection{Measure}

This stage is the search and measurement of the CTP (Critical to Process) or CTQ (Critical to Quality), which began with the search for VOC that was then broken down into something measurable.

Table 2: Voice of Customer

\begin{tabular}{|c|c|c|}
\hline$P$ & $O$ & $C$ \\
\hline Business Process & & Customer Process \\
\hline \multicolumn{3}{|l|}{ Heater System } \\
\hline Fuse often breaks down & & $\begin{array}{l}\text { Production } \\
\text { Department }\end{array}$ \\
\hline $\begin{array}{l}\text { Heater was often } \\
\text { damaged due to } \\
\text { damaged glowbar }\end{array}$ & $\begin{array}{l}\text { Took a long time for } \\
\text { the machine to } \\
\text { operate again }\end{array}$ & LOW DTE \\
\hline No treatment yet & & Fast Preheating \\
\hline $\begin{array}{l}\text { Area within holding } \\
\text { furnace contained a large } \\
\text { amount of dross }\end{array}$ & & $\begin{array}{l}\text { High Product } \\
\text { Output }\end{array}$ \\
\hline $\begin{array}{c}\text { Improvement Process } \\
\text { Availability of tools }\end{array}$ & & \\
\hline
\end{tabular}

In determining $\mathrm{CTP}$, the problems becoming top priority were those with the highest measurable damage downtime figures. The fuse is often damaged when in normal condition. The fuse was not damaged, and the DTE in January to June 2015 was 2,401 minutes. The glowbar with a lifetime of approximately 1 year, was often damaged with a frequency of damage at 2-3 times and DTE was 10,332 minutes. In the heater system process, the heater was not maintained where there should be maintenance. This occurred because there was no maintenance schedule for the heater system. There was a large amount of dross on the inside of the holding furnace area which should be cleaned. In the improvement process, the tools were supposed to be complete, but in reality they were not. Based on these data and CTP/CTQ improvement analysis, the downtime problem was caused by the impairment in the heater system and improvement process.

\subsection{DPMO Measurement}

This study discusses the improvement of machine performance by attempting to reduce DTE (downtime equipment). By reducing DTE it was expected that the machine performance would improve. The DMAIC method was employed to find out the root of the problem of the high DTE. The average working time from January to June 2015 was 150,000 and average heater DTE was 2,222. From the data, the sigma level average was 3.67 and average DPMO (Defect per Million Opportunities) value was 14,810.

\subsection{Analysis}

Identification of the root causes was completed by drawing the Ishikawa's fishbone diagram. The diagram is practical and was able to guide the team to continue to find out the main cause of an issue through brainstorming. Statistical testing was carried out on the root of the problem, including the main issue. This was to look at the root cause of the DTE due to heater damage and to determine priorities for improvement. Thus, studies on the following statements were conducted: whether the root cause of the glowbar damage posed significant impact on the heater's DTE and whether the root cause of the fuse damage posed significant impact on the heater's DTE.

The Pearson Product Moment, a technique developed by Karl Pearson to calculate correlation coefficients, was used in the correlation analysis in this study.

From analysis results, the correlation between the improvement of the glowbar and the downtime (DTE) with a significance value of $p=0,000$ and $\alpha=0.05$ means that $H_{1}$ is accepted and $\mathrm{H}_{0}$ is rejected. The correlation coefficient value (r) is positive, at 0.896 or $89.6 \%$, indicating that the direction of the correlation between the glowbar improvement and the downtime (DTE) is positive. In other words, both variables have a comparable correlation. Therefore, the $\mathrm{H}_{0}$ hypothesis in this study asserts that there is no significant impact of glowbar improvement on DTE. The rejection of $\mathrm{H}_{0}$ also indicates that the correlation between the improvement of the glowbar and the downtime (DTE) falls in the very strong category, in which the longer time it takes to repair the glowbar, the longer time the machine downtime takes.

Meanwhile in the Pearson correlation of fuse on DTE, the correlation between the improvement of the fuse and the downtime (DTE) with a significance value of $p=0,000$ and $\alpha$ $=0.05$ means that $\mathrm{H}_{1}$ is accepted and $\mathrm{H}_{0}$ is rejected. The correlation coefficient value $(r)$ is positive, at 0.628 or $62.8 \%$, indicating that the direction of the correlation between the fuse improvement and the downtime (DTE) is positive. In other words, both variables have an equal correlation. Therefore, the $\mathrm{H}_{0}$ hypothesis stating that there is no significant influence of fuse improvement on DTE is rejected, indicating that the correlation between the improvement of the fuse and the downtime (DTE) falls in the very strong category.

\subsection{Improvement}

The initial step of improvement from June to July 2015 was by improving the LPM line according to reparation schedule. After that, starting in August 2015 through the following months, the improvement results were used and monitoring was conducted to see the effectiveness of the improvement that has been done. The improvement for the adhered dross in the glowbar issue because the GBF (Gas Bubble Furnace) process was still carried out manually in the holding furnace was repaired with GBF carried out outside the holding furnace using the GBF machine. The improvement for glowbar material issue was to substitute steel with silicon nitride. For the current heater type problem which was $\varnothing 32$ $\mathrm{mm}$ (non-standard), the improvement was to standardize it by using the $\varnothing 38 \mathrm{~mm}$. For the cable heater skun that often melted due to the non-standard size of $16 \times 10$, the improvement was to standardize it by using the standard type size of $16 \times 25$. For the use of clamping heater using an iron that often caused the condition of clamping tenuous and the high ampere in heater, it could be fixed by substituting the clamping material of iron with copper. Issues such as incomplete tools, maintenance difficulties in making improvements, time-consuming reparation process, and use

\section{Volume 5 Issue 7, July 2016




\section{International Journal of Science and Research (IJSR) \\ ISSN (Online): 2319-7064}

Index Copernicus Value (2013): 6.14 | Impact Factor (2015): 6.391

of conventional tools could be solved by providing a special tool to repair the heater. The lack of maintenance schedule for the LPM machine heater could be improved by devising and implementing a maintenance schedule. The last issue was that the technicians' knowledge about electrical aspects was not evenly distributed. This problem could be solved by providing training.

\subsection{Control}

After the improvement phase, monitoring was needed to control the effectiveness of the improvement and to control the process so that it was stable and took place within the pre-determined time window. The line chart was used to monitor the results of the improvement.

Before improvement, in January DTE due to heater damage was 1,088; in February it was 4,079; in March it was 3,066; in April it was 1425; in May it was 2,273; and in June it was 1,398. After improvement, in July DTE was 764; in August it was 111; in September it was 38; in October it was 21; and in November it was 34 .

\section{Discussion}

\subsection{Downtime after improvement}

The aim of this study is to find out the critical factors of the root problem and then make improvements to reduce downtime due to heater damage. The results of the improvement can be seen in the previous section. The reduced downtime due to heater damage after the improvement can be seen in the following graph:

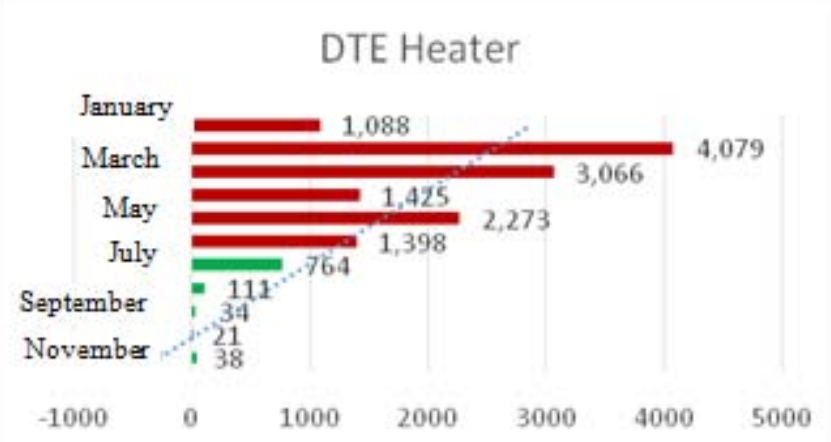

Figure 4: DTE due to heater damage

\subsection{Comparison of DPMO before and after improvement}

Regarding the efficiency in the use of spare parts, the company committing to make improvements would definitely wish to gain advantages, both financially and quality-wise. The improvement made had an impact on the use of spare parts.

In using spare parts, the company benefited from the material due to the reduced rate of parts replacement from July to November, with the fuse being replaced 6 times, the glowbar being replaced 18 times, and the heater being replaced 18 times. The use of spare parts from July to November 2015 was as follows:
Fuse Part $=$ Total of Part Replacement $\mathrm{x}$ Price of Part

$=6$ pcs x IDR 594,500

$=$ IDR 3,567,000

Glowbar Part $=$ Total of Part Replacement $\mathrm{x}$ Price of Part

$=18 \mathrm{pcs} \times$ IDR $8,800,000$

$=$ IDR $158,400,000$

Heater Part $=$ Total of Part Replacement $\mathrm{x}$ Price of Part

$=18$ pcs $x$ IDR $3,400,000$

$=$ IDR $61,200,000$

Other parts $=$ Lug + Clamp + Tools

$=$ IDR 30,000+ IDR 10,800,000 + IDR

$3,000,000$

$=$ IDR $13,830,000$

The total replacement of parts from July to November 2015 costed IDR 233,430,000. Therefore, the savings of the part replacement after the improvement is:

$=$ The total costs of part replacement before improvement the total costs of part replacement after improvement

$=$ IDR 323,327,000 - IDR 233,430,000

$=$ IDR $89,897,000$

\section{Conclusion}

1. The company had a problem in the machine downtime in the LPM line due to several item damages, especially the damage in the heater system which caused the longest downtime compared to the other item damages, and there were 9 (nine) root causes:

a) The glowbar had some splotches of dross adhered to it.

b) The glowbar was made of stainless steel

c) The heater was prone to breaking

d) The diameter of the lug was not appropriate

e) The clamp heater was made of iron

f) The tools were incomplete

g) No maintenance schedule was implemented

h) The manual GBF was inside the holding furnace.

i) The technicians' knowledge regarding maintenance of LPM heater was not yet evenly distributed

2. The machine downtime due to heater system damage reduced from an average of 3,000 minutes to 193 minutes per month, after the improvement, with a sigma value of 3.67 sigma before improvement and a value of 4.62 after improvement. After the improvement, the use of spare parts could be efficient by $27 \%$.

\section{References}

[1] Siringoringo, H., \& Sudiyantoro. (2004). Analisis Pemeliharaan Produktif Total Pada PT. Wahana Eka Paramitra GKD Group. Jurnal Teknologi \& Rekayasa, 9.

[2] Wahjudi, D., Tjitro, S., \& Soeyono, R. (2009). Studi Kasus Peningkatan Overall Equipment Effectiveness (OEE) Melalui Implementasi Total Productive Maintenance (TPM). In Prosiding Seminar Nasional Teknik Mesin IV 30 Juni 2009.

[3] Sharma, A., Yadava, G. S., \& Deshmukh, S. G. (2011). A literature review and future perspectives on maintenance optimization. Journal of Quality in Maintenance Engineering, 17(1), 5-25. 
[4] Al-Turki, U. (2011). A framework for strategic planning in maintenance. Journal of Quality in Maintenance Engineering, 17(2), 150-162.

[5] Simões, J. M., Gomes, C. F., \& Yasin, M. M. (2011). A literature review of maintenance performance measurement: A conceptual framework and directions for future research. Journal of Quality in Maintenance Engineering, 17(2), 116-137.

[6] Corder, Anthony. (1996). Teknik Manajemen Pemeliharaan. Jakarta: Erlangga.

[7] Borris, S. (2006). Total Productive Maintenance. United State of America: McGraw-Hill Companies, Inc.

[8] Ganguly, K. (2012). Improvement process for rolling mill through the DMAIC Six Sigma approach. International Journal for Quality Research, 6(3), 221230.

[9] Breyfogle III, F. W. (2003). Implementing six sigma: smarter solutions using statistical methods. John Wiley $\&$ Sons.

[10] Gaspersz,Vincent. (2007). Lean Six Sigma for Manufacturing and Service Industries.Jakarta : PT Gramedia Pustaka Utama.

\section{Author Profile}

Hadi Ashary pursued a Diploma 4 degree in Mechatronics at Politeknik Elektronika Negeri Sepuluh November Surabaya (PENS-ITS Surabaya) in 2006 and qualifying in 2010. Several nonformal education that he has participated in are VSM Training (Value Stream Management) in 2014, Jakarta, and Productivity Management Training in Jakarta in 2015. He worked as a Field Engineer at PT. Petrotec Air Power Jakarta in 2010 and is now a Supervisor at PT. Pakoakuina Jakarta, having been working there since 2011.

Choesnul Jaqin pursued an undergraduate program at FPTK IKIP Malang, and afterwards a masters and doctoral program at Kagoshima University. At present, he is a Lecturer at Mercu Buana University. 